Elsevier Editorial System(tm) for Journal of Archaeological Science

Manuscript Draft

Manuscript Number: JASC07-47R1

Title: Human ecological niches and ranges during the LGM in Europe derived from an application of ecocultural niche modeling

Article Type: Full Length Article

Keywords: Eco-cultural niche modeling; GARP; LGM; Solutrean; Epigravettian; Western Europe; Upper Paleolithic; Human adaptation

Corresponding Author: Dr William Ethan Banks, Ph.D.

Corresponding Author's Institution: Institut de Prehistoire et de Geologie du Quaternaire

First Author: William E Banks, M.A.; Ph.D.

Order of Authors: William E Banks, M.A.; Ph.D.; Francesco d'Errico, Ph.D.; A. Townsend Peterson, Ph.D.; Marian Vanhaeren, Ph.D.; Masa Kageyama, Ph.D.; Pierre Sepulchre; Gilles Ramstein, Ph.D.; Anne Jost, Ph.D.; Daniel Lunt, Ph.D.

Manuscript Region of Origin: FRANCE

Abstract: We apply eco-cultural niche modeling (ECNM), an heuristic approach adapted from the biodiversity sciences, to identify habitable portions of the European territory for Upper Paleolithic huntergatherers during the Last Glacial Maximum (LGM), circumscribe potential geographic extents of the Solutrean and Epigravettian technocomplexes, evaluate environmental and adaptive factors that influenced their distributions, and discuss this method's potential to illuminate past human-environment interaction. Our ECNM approach employed the Genetic Algorithm for Rule-Set Prediction (GARP) and used as input a combination of archaeological and geographic data, in conjunction with high-resolution paleoclimatic simulations for this time frame. The archaeological data consist of geographic coordinates of sites dated by Accelerator Mass Spectrometry to the LGM and attributed to the Solutrean and Epigravettian 
technocomplexes. The areas predicted by ECNM consistently outline the northern boundary of human presence at 22,000-20,000 cal BP. This boundary is mainly determined by climatic constraints and corresponds well to known southern limits of periglacial environments and permafrost conditions during the LGM. Differences between predicted ecological niches and known ranges of the Solutrean and Epigravettian technocomplexes are interpreted as Solutrean populations being adapted to colder and more humid environments and as reflecting influences of ecological risk on geographic distributions of cultures. 


\section{Human ecological niches and ranges during the LGM in Europe derived from an application of eco-cultural niche modeling}

William E. Banks ${ }^{1}$, Francesco d'Errico ${ }^{1,2}$, A. Townsend Peterson ${ }^{3}$, Marian Vanhaeren ${ }^{4}$, Masa Kageyama ${ }^{5}$, Pierre Sepulchre ${ }^{5}$, Gilles Ramstein ${ }^{5}$, Anne Jost $^{6}$, Daniel Lunt ${ }^{7}$

1 - Institut de Préhistoire et de Géologie du Quaternaire, UMR 5199-PACEA, Université Bordeaux1, CNRS, Bât. B18, Ave. des Facultés, 33405 Talence, France

2 - Department of Anthropology, George Washington University, 2110 G Street NW, Washington DC 20052

3 - Natural History Museum and Biodiversity Research Center, The University of Kansas, 1345 Jayhawk Blvd., Lawrence, KS 66045-7561, USA

4 - Ethnologie préhistorique, UMR 7041-ArScAn, Université de Paris X, CNRS, 21 allée de l'Université, 92023 Nanterre Cedex, France

5 - Laboratoire des Sciences du Climat et de l'Environnement/IPSL, UMR 1572, CEA/CNRS/UVSQ, Saclay, L'Orme des Merisiers, Bât. 701, 91191 Gif-sur-Yvette Cedex, France

${ }^{6}$ - UMR 7619 SISYPHE, Université Pierre-et-Marie Curie Paris VI, Boite 123, 4 Place Jussieu, 75252 Paris Cedex 05

${ }^{7}$ - School of Geographical Sciences, University Road, University of Bristol, Bristol, BS8 1SS, United Kingdom

\footnotetext{
Abstract

We apply eco-cultural niche modeling (ECNM), an heuristic approach adapted from the biodiversity sciences, to identify habitable portions of the European territory for Upper Paleolithic hunter-gatherers during the Last Glacial Maximum (LGM), circumscribe potential geographic extents of the Solutrean and Epigravettian
} 
technocomplexes, evaluate environmental and adaptive factors that influenced their distributions, and discuss this method's potential to illuminate past human-environment interaction. Our ECNM approach employed the Genetic Algorithm for Rule-Set Prediction (GARP) and used as input a combination of archaeological and geographic data, in conjunction with high-resolution paleoclimatic simulations for this time frame. The archaeological data consist of geographic coordinates of sites dated by Accelerator Mass Spectrometry to the LGM and attributed to the Solutrean and Epigravettian technocomplexes. The areas predicted by ECNM consistently outline the northern boundary of human presence at $22,000-20,000$ cal BP. This boundary is mainly determined by climatic constraints and corresponds well to known southern limits of periglacial environments and permafrost conditions during the LGM. Differences between predicted ecological niches and known ranges of the Solutrean and Epigravettian technocomplexes are interpreted as Solutrean populations being adapted to colder and more humid environments and as reflecting influences of ecological risk on geographic distributions of cultures.

\section{Introduction}

The idea of modeling past human-environmental interactions is by no means new. Researchers have used archaeological and environmental data sets, and diverse methods, to interpret prehistoric hunter-gatherer behavior in ecological contexts. Well-known European examples concern prehistoric population distributions during Oxygen Isotope Stages 2 and 3 (Gamble et al., 2004; Van Andel and Davies, 2003), as well as the resettlement of regions following severe climatic episodes (Gamble et al., 2005; Straus et 
al., 2000). These studies were based on spatial distributions of radiometrically dated sites and generalized climatic reconstructions. Others have used a similar approach to estimate population size and kinetics (Bocquet-Appel and Demars, 2000; Bocquet-Appel et al., 2005). More detailed attempts to examine population distributions and human tolerances with respect to environmental variability also exist (Binford, 1999, 2001; Davies et al., 2003; d'Errico and Sanchez Goni, 2003; d'Errico et al., 2006; Sepulchre et al., 2007). However, no agreement yet exists on how best to evaluate influences of environmental factors on prehistoric human populations and their responses to climatic variability.

One common limitation is the use of coarse-scale climatic data (i.e., simulations with resolutions of $3-5^{\circ}$ in latitude and longitude) and imprecise chronological data (i.e., reliance on old conventional ages with large sigmas) that make evaluation of human responses to rapid-scale climatic variability, with adequate resolution, difficult. Another shortfall of previous studies is that they have incorporated environmental data into analyses only passively, such that these data are used as backdrops against which the archaeological record is interpreted. While these studies have obvious value, they are limited in their ability to evaluate prehistoric hunter-gatherer responses to the abrupt climatic and environmental changes of the last glacial period. The need for robust methods with which to evaluate more precisely how past human and animal populations responded to these changes is critical.

An important recent advance in the study of biological diversity has been the development of biocomputational architectures for predictive modeling of complex biodiversity phenomena (Guisan and Zimmermann, 2000; Soberón and Peterson, 2005). Such tools can be used to predict species' range (i.e., ecological niche) expansion or 
contraction in response to real or simulated climatic changes (Peterson et al., 2002). The ecological niche of a species can be defined as the range of environmental conditions within which it can persist without immigrational subsidy (Grinnell, 1924; Hutchinson, 1957). Such methods have considerable potential for reconstructing niches of past human populations and for illuminating the complex mechanisms that regulated the interactions between past hunter-gatherer populations and their environments, which in turn helped shape cultural, genetic, and linguistic geographies. These methods, and related concepts, recently have been termed Eco-Cultural Niche Modeling (ECNM) (Banks et al., 2006) when applied to prehistoric human populations. Our application of ECNM interactively integrates climatic, geographic, and archaeological data via a machine-learning genetic algorithm, described below. Comparable work is being pursued by others to analyze North American Paleoindian (Anderson and Gillam in Banks et al., 2006) and Far Eastern Paleolithic (Gillam and Tabarev, 2006) data and have shown promising results. We argue that ECNM is a powerful approach and, when paired with high-resolution climatic simulations, allows one to overcome many limitations of previous studies and evaluate prehistoric human-environment interactions at regional scales.

Here, we apply ECNM to human populations at the Last Glacial Maximum (LGM) in Europe, a well-studied and dated climatic phase known to have had profound impacts on human populations, with three primary objectives: (1) to determine the limits of the potential human range during the LGM, (2) to define the eco-cultural niches of the two main archeological cultures present in Europe at that time (the Solutrean and Epigravettian technocomplexes), and (3) to identify environmental and cultural factors that shaped their geographic ranges. 


\section{Environmental and Cultural Context}

The last glacial period was marked by dramatic and rapid climatic variability (Dansgaard et al., 1993; Johnsen et al., 1992), with the LGM representing a unique suite of climatic conditions (Ditlevsen et al., 1996; Peryon et al., 1998). This period, centered on $21 \mathrm{kyr}$ cal BP, is characterized by the maximum volume of the ice sheet over Scandinavia and northern Europe, along with cold and generally arid conditions in northern and Western Europe. The LGM archaeological record is characterized by a relatively small number of sites and large gaps in the archaeological record for many regions (cf. Soffer and Gamble, 1990; Straus, 2005; Street and Terberger, 1999). Such a pattern has been interpreted to be the result of the human abandonment of northern Europe and a contraction of the human range to southern regions that served as refugia. Such contraction and consequent demographic reduction is known to have produced a bottleneck in human genetic diversity (Barbujani et al., 1998:490; Torroni et al., 1998; Torroni et al., 2001).

In Western Europe, between ca. 22 kyr and 20 kyr cal BP, human groups responded to LGM environmental conditions by developing a suite of new technologies characterized by a variety of diagnostic projectile points and knives produced by bifacial retouch (Figure 1A), which define the Solutrean (Mortillet, 1873; Smith, 1966). Straus (2005) proposed that Solutrean populations employed more specialized subsistence systems, relative to earlier Upper Paleolithic technocomplexes, to exploit regions rich in game but under harsh climatic conditions.

In the regions of southeastern Europe, hunter-gatherers of the LGM produced a 
different lithic technology, termed the early Epigravettian (Laplace, 1964; Mussi, 2001), characterized by shouldered and backed projectile points produced by unifacial retouch (Figure 1B). Leaf-shaped points are rare and have been recovered from only a few sites in northern Italy (Palma di Cesnola, 1990). Contrary to the Solutrean, which appears as a novel technology, the Epigravettian toolkit is interpreted as being derived from the preceding Gravettian technocomplex (Otte, 1990; Palma di Cesnola, 2001).

\section{Materials and Methods}

For ECNM, we employed a machine-learning genetic algorithm originally developed for determining the ecological niches of plant and animal species (Stockwell, 1999; Stockwell and Peters, 1999). This software application, termed the Genetic Algorithm for Rule-Set Prediction (GARP), has been applied to topics as diverse as habitat conservation, effects of climate change on species' distributions, the geographic potential of species' invasions, and anticipation of emerging disease transmission risk (Adjemian et al., 2006; Martinez-Meyer et al., 2004; Peterson et al., 2004; Sanchez-Cordero and Martinez-Meyer, 2000; Soberón and Peterson, 2004). It is available for download at http://www.lifemapper.org/desktopgarp/.

GARP requires as input the geographic coordinates where the target species has been observed and raster GIS data layers summarizing environmental variables that may be involved in limiting the geographic distribution of the species. In our application, the occurrence data were the geographic coordinates of radiometrically dated and culturally attributed archaeological sites. These archaeological data were obtained from a database, compiled by FdE and MV, that contains the geographic coordinates, recorded 
stratigraphic levels, associated cultural affiliations, and $>6000$ radiometric ages from ca. 1300 archaeological sites in Europe.

The raster GIS data consisted of landscape attributes and high-resolution climatic simulations for the LGM. The landscape variables included slope, aspect, elevation, and compound topographic index (a measure of tendency to pool water) from the Hydro-1K dataset (U.S. Geological Survey's Center for Earth Resources Observation and Science http://edc.usgs.gov/products/elevation/gtopo30/hydro/index.html).

Typically, climatic simulations for specific periods of time are produced by forcing general circulation models (GCMs), which reconstruct past, present, and future climates globally typically at resolutions where grid squares measure $100-200 \mathrm{~km}$ on a side. For instance, the LGM and the mid-Holocene have been the focus of coordinated experiments in the framework of the Paleoclimate Modelling Intercomparison Project (Harrison et al., 2002; Joussaume and Taylor, 1995; PMIP, 2000). In an effort to use climatic data that approach the same scale of resolution as our geographic data, we use in the present study a regional climatic simulation with a grid box size over Europe of $\sim 60$ $\mathrm{km}$ on a side, which was run at the Laboratoire des Sciences du Climat et de l'Environnement, Gif-sur-Yvette, France.

This high-resolution LGM atmospheric simulation followed the PMIP1 protocol (http://www-lsce.cea.fr/pmip), with sea-surface temperatures and sea ice cover as prescribed from the CLIMAP (1981) data set and the ice-sheets from the Peltier (1994) ICE-4G reconstruction. Atmospheric $\mathrm{CO}_{2}$ concentration was lowered to $200 \mathrm{ppmv}$ according to the ice-core record (Raynaud et al., 1993) and orbital parameters adjusted to 21,000 cal BP values (Berger, 1978). The results of this simulation have been compared 
to pollen-based climatic reconstructions, with fairly close agreement for summer and annual mean temperatures but some underestimation of winter cooling and drying over Western Europe and the Mediterranean (Jost et al., 2005). From this simulation, we derived the following variables for input into GARP: warmest month temperature, coldest month temperature, mean annual temperature, and mean annual precipitation (Figure 2). The values of warmest and coldest months refer to the warmest/coldest month in a climatic cycle averaged over $10 \mathrm{yr}$ of simulation.

In GARP, geographic locations of archaeological sites are resampled randomly by the algorithm to create training and test data sets. An iterative process of rule selection is then performed within the program's functioning, in which an inferential tool is chosen from a suite of possibilities (e.g., logistic regression, bioclimatic rules) and applied to the training data to develop specific rules (Stockwell 1999). These rules maximize predictivity by using independent data to evaluate them. Predictive accuracy is evaluated based on the known presence data and a set of pseudoabsence points (i.e., points sampled randomly from among points across the region of study where the species has not yet been detected) (Stockwell 1999). This evaluation process is used to develop a rule-set that defines the distribution of a species in ecological space (i.e., an ecological niche) (Soberón and Peterson, 2005), which can be projected onto the landscape to predict a potential geographic distribution (Peterson, 2003:421; Stockwell, 1999; Stockwell and Peters, 1999). GARP has undergone extensive improvement and testing in recent years, including detailed sensitivity analyses (Peterson and Cohoon, 1999; Stockwell and Peterson, 2002a, 2002b; Anderson et al., 2002).

We applied GARP to archaeological sites dated by AMS to the LGM, in an effort 
to minimize the possibility of incorporating sites for which radiometric determinations are underestimates of true ages, as has been shown to be common for older Upper Paleolithic technocomplexes that date to the temporal limits of radiocarbon methods (d'Errico and Sanchez-Goni, 2003; Van der Plicht, 1999; Zilhão and d'Errico, 1999). The lack of agreement between conventional and AMS ages has been attributed by these authors to ineffective sample treatments, and the application of conventional ${ }^{14} \mathrm{C}$ counting methods to samples that fall near the limits of this dating method. While these factors should have a lesser impact concerning sites dated to the LGM, they still may be a source of error considering this period's relatively narrow time window. Figure 3, presenting distributions of conventional and AMS ages from sites attributed to the Solutrean, indicates that such sources of error are present for ages during the LGM: conventional ages are slightly younger relative to AMS ages, suggesting that some underestimate the true age of their sites.

For this reason, the site samples used to create our Solutrean and Epigravettian ECNMs are composed primarily of sites radiometrically dated by AMS to the height of the LGM (defined here as $21 \pm 1 \mathrm{kyr}$ cal BP), and that contain diagnostic material assemblages associated with these technocomplexes (Table 1). AMS ages for sites assigned to the two technocomplexes of interest were calibrated using CALIB 5.0.2html (Reimer et al., 2004; Stuiver et al., 2005). The geographic coordinates of those sites that fell within our targeted time frame were used as occurrence points. We included 5 undated sites in Italy reliably attributed to the early Epigravettian of the LGM based on their stratigraphic contexts and diagnostic material assemblages to increase sample size for this technocomplex. 
The other exception to our site selection protocol is the Solutrean site of Buraca Escura. The conventional age from this site (Gif-4585) is very similar to the AMS ages from nearby Solutrean sites that, when calibrated, fall just outside the LGM timeframe. In all, geographic coordinates for 11 Epigravettian and 9 Solutrean sites were used as input to produce the GARP models.

We used the following specifications in GARP. Given the random walk nature of the method, we ran 1000 replicate runs, with a convergence limit of 0.01 . Given the small size of the samples, we used ca. $80 \%$ of occurrence points for developing training rules in each analysis and reserved one point for model selection and one for evaluating model predictive ability. We then followed a protocol for selecting among the resulting models (Anderson et al., 2003), with omission error (i.e., failure to predict a known presence) measured based on the single reserved model selection point (see above), and models retained only when they were able to predict that single point (i.e., hard omission threshold of $0 \%$ ). Commission error, conversely, is a measure of areas of absence that are incorrectly predicted present (Anderson et al., 2003:213). We followed recommendations of removing from consideration those $50 \%$ of models that show extreme values of proportional area predicted present. The resulting final 'best-subset' models ( $N=10$ for each technocomplex) were then summed to produce a best estimate of the potential geographic distribution for each technocomplex. This same procedure was used with all sites combined, regardless of cultural affiliation, to predict potential human range during the LGM.

Predictive models such as ECNMs are just that—predictions. As such, ECNMs must be tested for predictive accuracy before they can be interpreted. Given low 
occurrence data samples, we tested model predictions using the jackknife manipulation proposed by Pearson et al. (2007), which is the only robust test for evaluating models based on small samples. Here, we used the single point set aside for evaluating model predictivity: if $N$ occurrence points are available, $N-1$ points are used to develop $N$ jackknifed models. The success of each replicate model in predicting the single point that was omitted, relative to the proportional area predicted present, is then calculated using an extension to the cumulative binomial probability distribution (Pearson et al., 2007).

To evaluate whether the two technocomplexes reflect adaptations to different ecological regimes, we compared their respective ecological niches. First, we performed a Principal Component Analysis using Statistica 7.1 on the climatic and geographic variables' values for the grid squares with a predicted presence for all 10 GARP bestsubset models. Based on the results, described below, the values for mean annual precipitation, mean annual temperature, coldest month temperature, and warmest month temperature of these best-subset grid squares were plotted against all the available climatic data of the LGM simulation.

\section{Results}

The model produced using both Solutrean and Epigravettian sites identifies a clear northern boundary for potential human range during the LGM (Figure 4), which is also reproduced in the models for each separate technocomplex (Figure 5). This boundary follows the Loire valley in France, excludes the Massif Central, includes the Mediterranean regions of France, follows the southern limit of the Alps, and the northern limits of the Carpathian range (Figure 4). 
The territories predicted for the Solutrean and the Epigravettian are presented individually in Figure 5. The Solutrean model predicts potential presence of human groups associated with this culture in southwestern and southern France, northwestern portions of the Iberian Peninsula, the Ebro valley, and in disjunct areas of Cantabria, northwestern Italy, and the Balkans. The model for the Epigravettian predicts a potential presence of this culture in the Balkans, the Italian Peninsula excluding the most southerly regions, the Mediterranean regions of France as well as the Aude and Garonne corridors, and the Iberian Peninsula excluding its southern regions. That these models have high predictive power regarding potential human distributions is shown by the accuracy observed in the jackknife manipulations. The independent test point was correctly predicted in 7 of the 9 jackknife models for the Solutrean and in all 11 models for the Epigravettian, with associated probabilities of $P=0.00005$ and $P<0.00001$, respectively.

Although potential distributions predicted for these two technocomplexes show only minimal overlap geographically, conclusions of ecological differentiation are complex. These models are geographic projections of ecological niches defined by multiple environmental variables, so small differences between ecological niches can result in different potential geographic distributions when ecological differences correspond to environmental conditions present over large regions.

A Principal Component Analysis of the environmental variables indicated that overall environmental variability in the study area is satisfactorily explained (85\%) by the first two components, which are most influenced by the different temperature variables associated with each technocomplex's predicted distribution. Plotting the climatic variables' values of the grid squares where all best-subset models predicted potential 
presence against all of the available climatic data (Figure 6) showed that the ecological niches occupied by the two technocomplexes overlap broadly, with only slight differences on the edges of their predicted niches. These differences indicate that the Solutrean technocomplex had the potential to occupy somewhat cooler and more humid environments than the Epigravettian. T-tests performed on these data matrices to compare the two technocomplexes were uniformly significant $(\mathrm{p}<<0.05)$, indicating that the Solutrean and Epigravettian niches are not drawn from the same population.

\section{Discussion}

The northern limits of the human range predicted by ECNM for the LGM (Figure 4) are arguably accurate. These limits are consistent with the known distribution of archaeological sites for this period (Bocquet-Appel et al., 2005; Demars, 1996; Soffer and Gamble, 1990). The only radiometrically dated site for our temporal range that seemingly contradicts our results is that of Wiesbaden-Igstadt (Street and Terberger, 1999), which has yielded 7 AMS ages from a single occupation level ranging from 19,320-17,210 B.P. Street and Terberger (1999:267) think that these ages collectively represent the true age of the site but acknowledge, however, that uncertainties (e.g., contamination) could exist. When calibrated, two of these dates (UZ-3768 and OxA7500) fall within our LGM window, but they are appreciably younger than the other calibrated dates from the same level suggesting that they underestimate the true age of the occupation. This interpretation is supported by the fact that when these two ages are averaged $\left(t_{\text {ave }}=17,356 \pm 118\right.$ B.P. $)$ using the method described by Long and Rippeteau (1974), and compared to the next youngest age (OxA-7501), the null hypothesis of no 
difference is rejected $(t=4.0143, P<0.001)$. Because the younger and older ages from Wiesbaden-Igstadt cannot be considered to be drawn from the same statistical population, and the older ages fall before the LGM when calibrated, we hesitate to accept that this site represents an LGM human occupation of the Central Rhineland. Wiesbaden-Igstadt probably dates to Dansgaard-Oeschger Interstadial 2 to which Shackleton et al. (2004:1515) assign an age of $19.62 \pm 0.21 \mathrm{kyr}$ BP.

One might argue that the site samples used in our study are not representative of human population distributions, especially with respect to northern limits, during the LGM. In other words, some regions may have been only sporadically occupied leaving undetectable archaeological signatures. Such an argument is contradicted by statistical analyses (Bocquet-Appel et al., 2005) that convincingly show that the frequencies and distributions of recorded archaeological sites in Europe are representative, when considered with an appropriate taphonomic perspective, of prehistoric population distributions. Considering these arguments, the northern latitudinal limits of human occupation during the LGM indicated by our ECNM predictions represent accurate estimates of the areas occupied by hunter-gatherers during this period.

Interestingly, the northern range of the GARP predictions corresponds to the southern boundaries of periglacial environments in Western and Central Europe (Huijzer and Vandenberghe, 1998; Lautridou and Sommé, 1981). The GARP limits in France follow closely those that separated regions characterized by continuous deep permafrost [depths of 50-600m (van Vliet-Lanoë, 2005:94)] and continuous permafrost (Figure 7) (van Vliet-Lanoë et al., 2004). The limits predicted by the ECNM for southern France, Iberia, and Italy generally follow the boundary between continuous and discontinuous 
permafrost (Texier, 1996; vanVliet-Lanoë, 1996). Such correspondence strengthens arguments for the predictive power of our modeling approach since periglacial environments have low biomass, which may have prevented systematic utilization by prehistoric human groups.

The geographic distributions predicted by the ECNMs for the Solutrean and Epigravettian show only minimal overlap (Figure 5), suggesting that the populations associated with these two technocomplexes were to some degree adapted to different environments. Reconstructions of their ecological niches indicate that they overlap broadly, but that Solutrean populations were able to exploit colder and more humid areas, corresponding to areas with permanent permafrost during the LGM. In contrast, Epigravettian populations seem to have been more adapted to areas dominated by discontinuous permafrost and seasonal freezing. Neither technocomplex is associated with the more southerly, dry, and relatively warmer Mediterranean environments during the LGM.

It is important to point out that GARP identifies the potential ecological niche for a population and not necessarily the actual distribution as determined by cultural and historical contingencies. With respect to the correspondence between predicted and actual geographic ranges, the relatively restricted potential geographic distribution for the Solutrean corresponds well to this technocomplex's archaeological distribution. In contrast, the Epigravettian ECNM prediction exhibits a potential range across southern France and Spain that is not corroborated archaeologically. This phenomenon is common (Peterson 2003) when species' predicted ecological niches are projected across broad geographic areas: habitable areas are frequently predicted outside their observed range. 
Four factors are generally cited to account for such discordances: (1) limited dispersal, (2) speciation, (3) extinction on regional scales, and (4) competitive exclusion (Peterson, 2003:422-423). Limited dispersal refers to the inability of a species to occupy other regions due to physical mobility constraints, which does not seem to apply to the Epigravettian populations since coastal corridors were open and habitable during the LGM and would have allowed them to colonize western territories. Speciation also is not a factor since human populations that occupied Europe at the end of OIS 3 and during OIS 2 arguably belonged to the same species. Likewise, regional extinction is not applicable, as it implies that Epigravettian populations were present in those regions before the LGM, but went extinct before its onset. The archaeological record demonstrates that such is not the case.

Of the factors proposed by Peterson (2003), competition may explain the discordance between actual and predicted Epigravettian distributions since GARP only models the potential niche of one population at a time. The competition hypothesis implies that Epigravettian populations could not occupy suitable regions of Western Europe, such as the northern Iberian Peninsula, because it would have been necessary to cross large areas occupied by competing human groups bearing a different cultural tradition, the Solutrean. This idea raises the question of why such competition would create a boundary between human groups, instead of resulting in occupation of the entire potentially exploitable geographic area by only one of them.

In the case of a biological species, the reasons that create a boundary between competing species are mainly ecological (MacArthur, 1972; Hutchinson, 1978). With humans, other factors can play roles in creating boundaries between groups. Contrary to 
most animal species, the carrying capacity of a human population is directly linked to its ability to maintain and transmit between generations not only a suitable technical system, but also a complex and dynamic set of social rules, cultural and religious values, systems of symbols, language, and ethnic identity. The geographic extent over which this heritage can be maintained may vary according to the nature of each human culture but is also highly dependent, particularly for hunter-gatherers, on ecological constraints. Nettle (1998) demonstrated convincingly that the geographic extent of linguistic entities increases in regions of high ecological risk, where ecological risk is defined as the amount of variation which people face in their food supply over time (seasonally or interannually). Collard and Foley (2002) argued that cultural diversity decreases towards higher latitudes. Both studies attribute this pattern to the need to create long-distance social networks to increase the ability of human groups to survive in hostile environments. Limits to the expansion of such cultural and linguistic entities are thus arguably dictated by the need to maintain a degree of cultural and linguistic cohesiveness over these large ranges. The reconstructed ecological niches and their geographic projections for the two technocomplexes suggest that they occupied regions associated with different levels of ecological risk. Solutrean populations principally exploited regions characterized by colder and more humid conditions than those occupied by Epigravettian groups.

Good agreement exists between the predicted eco-cultural range for the Solutrean technocomplex and its actual archaeological distribution. We contend that Solutrean populations faced relatively high levels of ecological risk and consequently occupied as much of the potential geographic distribution allowed by their cultural adaptation as 
possible. Geographical barriers such as the Pyrenees and the Cantabrian range apparently were not obstacles to the occupation of their entire niche. In contrast, Epigravettian populations showed marked differences between potential and actual distributional areas. We suggest that Epigravettian groups faced lower levels of ecological risk and thus did not need to extend spatially as broadly.

Additionally, the potential geographic range predicted by the ECNM for the Epigravettian technocomplex during the LGM is restricted to a latitudinal band determined by geographic barriers (western Alps and Pyrenees)—given the narrowness of the European Mediterranean coastline, corridors between areas suitable for Epigravettian groups would have been restricted. Such irregular potential distributional areas would certainly have constituted major obstacles to maintenance of viable cultural and linguistic networks across these regions. These restrictions were probably more effective between the Italian and Iberian Peninsulas than between the Italian Peninsula and the Balkans owing to the broad Adriatic plain created by low sea levels during the LGM (Antonioli et al., 2004; Lambeck et al., 2004). This difference certainly facilitated exchange between populations of the Italian Peninsula and southeastern Europe, as supported by Epigravettian affinities to LGM industries of the Balkans (Montet-White, 1996:121-122).

\section{Conclusions}

ECNM is an effective approach by which to characterize and quantify ecocultural niches associated with specific technocomplexes, and better understand how environmental factors influenced distributions of prehistoric human populations. Future 
research must focus on methods that can be used to evaluate more precisely the roles of competition and cultural cohesiveness in producing discords between predicted and actual ranges. The role of geography in constraining niches and creating cultural boundaries must be specifically targeted. Comparisons between the extent and location of niches occupied by populations associated with specific technocomplexes under similar climatic and environmental conditions may allow us to better disentangle the influences of environmental and cultural factors. It also would be useful to apply these techniques to animal species of the LGM and other climatic episodes to evaluate whether or not their predicted ecological niches were associated with those of humans. Finally, the application of ECNM to historically documented hunter-gatherers, for which detailed cultural and environmental data are available and cultural dynamics have been directly observed, would be instrumental in interpreting predictions based on archaeological and paleoclimatic data.

Acknowledgements: We thank María Fernanda Sánchez Goñi, Marco Peresani, and Paolo Biagi for helpful discussions, and Françoise LaGarde for making Figure 7. We especially thank Barbara Wohlfarth for her support as leader of RESOLuTION, a project with the European Science Foundation's EuroCores on EuroCLIMATE program, which made this research possible. We also thank the two anonymous reviewers whose comments improved the manuscript. Of course, any remaining shortcomings remain the responsibility of the principal author. This research was also funded by the OMLL program of the European Science Foundation, a post-doctoral grant given to one of us 
(WEB) by the Centre National de la Recherche Scientifique, the French Ministry of

Research (ACI Espace et territoires), and the ECLIPSE programme of the CNRS.

\section{References Cited}

Adjemian, J.C.Z., Girvetz, E.H., Beckett, L., Foley, J.E., 2006. Analysis of Genetic Algorithm for Rule-Set Production (GARP) modeling approach for predicting distributions of fleas implicated as vectors of plague, Yersinia pestis, in California. Journal of Medical Entomology 43, 93-103.

Anderson, R.P., Gómez, M., Peterson, A.T., 2002. Geographical distributions of spiny pocket mice in South America: Insights from predictive models. Global Ecology and Biogeography 11, 131-141.

Anderson, R.P., Lew, D., Peterson, A.T., 2003. Evaluating predictive models of species' distributions: criteria for selecting optimal models. Ecological Modelling 162, 211-232.

Antonioli, F., Lambeck, K., Amorosi, A., Belluomini, G., Correggiari, A., Devoti, S., Demuro, S., Monaco, C., Marocco, R., Pagliarulo, R., Orru, P., Silenzi, S., 2004. Sea level at 8 and $22 \mathrm{ka}$ cal BP along the Italian coastline. In: Climax Maps Italy:

Explanatory notes. F. Antonioli, F., Vai, G.B.(eds.). Bologna, Italy, pp.11-14

Banks, W.E., d'Errico, F. , Dibble, H.L., Krishtalka, L., West, D., Olszewski, D.I., Peterson, A.T., Anderson, D.G., Gillam, J.C., Montet-White, A., Crucifix, M., Marean, C.W., Sanchez-Goni, M.-F., Wolfarth, B., Vanhaeran, M., 2006. Eco-cultural niche modeling: New tools for reconstructing the geography and ecology of past human populations. PaleoAnthropology 4, 68-83.

Barbujani, G., Bertorelle, G., Chikhi, L., 1998. Evidence for Paleolithic and Neolithic gene flow in Europe. American Journal of Human Genetics 62, 488-491.

Berger, A., 1978. Long-term variations of caloric solar radiation resulting from the earth's orbital elements. Quaternary Research 9, 139-167.

Binford, L.R., 1999. Time as a Clue to Cause? Proceedings of the British Academy 101, $1-35$.

Binford, L.R., 2001. Constructing Frames of Reference: An Analytical Method for Archaeological Theory Building Using Hunter-Gatherer and Environmental Data Sets. University of California Press, Berkeley.

Bocquet-Appel, J.-P., Demars, P.-Y., 2000. Population kinetics in the Upper Paleolithic of Western Europe. Journal of Archaeological Science 27, 551-570. 
Bocquet-Appel, J.-P., Demars, P.-Y., Noiret, L., Dobrowsky, D., 2005. Estimates of Upper Paleolithic meta-population size in Europe from archaeological data. Journal of Archaeological Science 32, 1656-1668.

CLIMAP, 1981. Seasonal reconstructions of the Earth's surface at the last glacial maximum. Map Chart Series MC-36, Geological Society of America, Boulder, Colorado.

Collard, I.F., Foley, R.A., 2002. Latitudinal patterns and environmental determinants of recent human cultural diversity: Do humans follow biogeographical rules? Evolutionary Ecology Research 4, 371-383.

Dansgaard, W., Johnsen, S.J., Clausen, H.B., Dahl-Jensen, D., Gundestrup, N.S., Hammer, C.U., Hvidberg, C.S., Steffensen, J.P., Sveinbjörnsdóttir, A.E., Jouzel, J., Bond, G.C., 1993. Evidence for general instability of past climate from a $250 \mathrm{kyr}$ ice-core record. Nature 264, 218-220.

Davies, W., Valdes, P., Ross, C.A., van Andel, T., 2003. The human presence in Europe during the last glacial period III: site clusters, regional climates, and resource attractions. In: van Andel, T., Davies, W. (Eds.), Neanderthals and Modern Humans in the European Landscape during the Last Glaciation. McDonald Institute for Archaeological Research, Cambridge, pp. 191-220.

Demars, P.-Y., 1996. Démographie et occupation de l'espace au Paléolithique supérieur et au Mésolithique en France. Préhistoire Européene 8, 3-26.

d'Errico, F., Sánchez-Goñi, M.-F., 2003. Neanderthal extinction and the millennial scale climatic variability of the OIS 3. Quaternary Science Reviews 22, 769-788.

d'Errico, F., Sánchez-Goñi, M.-F., Vanhaeren, M., 2006. L’impact de la variabilité climatique rapide des OIS3-2 sur le peuplement de l'Europe. In: L'Homme face au Climat, Bard, E. (Ed.). Odile Jacob, Paris, pp. 265-282.

Ditlevsen, P.D., Svensmark, H., Johnsen, S., 1996. Contrasting atmospheric and climate dynamics of the last-glacial and Holocene periods. Nature 379, 810-812.

Gamble, C., Davies, W., Pettitt, P., Richards, M., 2004. Climate change and evolving human diversity in Europe during the last glacial. Philosophical Transactions of the Royal Society of London B359, 243-254.

Gamble, C., Davies, W., Pettitt, P., Hazelwood, L., Richards, M., 2005. The archaeological and genetic foundations of the European population during the Late Glacial: Implications for 'agricultural thinking.' Cambridge Archaeological Journal 15, 193-223.

Gillam, J.C., Tabarev, A.V., 2006. Geographic information systems and predictive modeling: Prospects for Far East archaeology. In: Archaeological Elucidation of the 
Japanese Fundamental Culture in East Asia. Kokugakuin Univeristy $21^{\text {st }}$ Century COE Program, Tokyo, Archaeology Series 7, 63-76.

Grinnell, J., 1924. Geography and evolution. Ecology 5, 225-229.

Guisan, A., Zimmermann, N.E., 2000. Predictive habitat distribution models in ecology. Ecological Modelling 135, 147-186.

Harrison, S., Braconnot, P., Hewitt, C., Stouffer, R.J., 2002. Fourth international workshop of the Palaeoclimate Modelling Intercomparison Project (PMIP): launching PMIP Phase II. EOS 83, 447-447.

Huijzer, B., Vandenberghe, J., 1998. Climate reconstruction of the Weichselian Pleniglacial in northwestern and central Europe. Journal of Quaternary Science 13, 391417.

Hutchinson, G.E., 1957. Concluding Remarks. Cold Spring Harbor Symposium on Quantitative Biology 22, 415-457.

Hutchinson, G.E., 1978. An Introduction to Population Ecology. Yale University Press, New Haven, Connecticut.

Johnsen, S.J., Clausen, H.B., Dansgaard, W., Fuhrer, K., Gundestrup, N., Hammer, C.U., Iversen, P., Jouzel, J., Stauffer, B., Steffensen, J.P., 1992. Irregular glacial interstadials recorded in a new Greenland ice core. Nature 359, 311-313.

Jost, A., Lunt, D., Kageyama, M., Abe-Ouchi, A., Peyron, O., Valdes, P.J., Ramstein, G., 2005. High-resolution simulations of the last glacial maximum climate over Europe: a solution to discrepancies with continental palaeoclimatic reconstructions? Climate Dynamics 24, 577-590.

Joussaume, S., Taylor, K.E., 1995. Status of the Paleoclimate Modeling Intercomparison Project (PMIP). In: Proceedings of the Firs International AMIP Scientific Conference. vol. WRCP-92, 15-19 May 1995, Monterey, CA, USA, pp. 425-430.

Lambeck, K., Antonioli, F., Purcell, A., Silenzi, S., 2004. Sea-level change along the Italian coast for the past 10,000 yr. Quaternary Science Reviews 23, 1567-1598.

Laplace, G., 1964. Les subdivisions du Leptolithique italien: Etude de typologie analytique. Bulletin di Paletnologia Italiana, Vol. 73.

Lautridou, J. P., Sommé, J. 1981. L'extension des niveaux-repères périglaciaires à grandes fentes de gel de la stratigraphie du Pléistocène récent dans la France du NordOuest. Biuletyn Periglacjalny 28, 179-185 
Long, A., Rippeteau, B., 1974. Testing contemporaneity and averaging radiocarbon dates. American Antiquity 39, 205-215.

MacArthur, R., 1972. Geographical Ecology. Princeton University Press, Princeton, N.J.

Martinez-Meyer, E., Peterson, A.T., Hargrove, W.W., 2004. Ecological niches as stable distributional constraints on mammal species, with implications for Pleistocene extinctions and climate change projections for biodiversity. Global Ecology and Biogeography 13, 305-314.

Montet-White, A., 1996. Le Paléolithique en ancienne Yougoslavie. Série "Préhistoire d'Europe" No. 4, Jérôme Million, Grenoble.

Mortillet, G. de, 1873. Classification des diverses périodes de l'Age de la Pierre. C.I.A.A.P., C.R. 6th session, Brussels (1872).

Mussi, M., 2001. Earliest Italy: An Overview of the Italian Paleolithic and Mesolithic. Kluwer Academic/Plenum Publishers, New York.

Nettle, D., 1998. Explaining global patterns of language diversity. Journal of Anthropological Archaeology 17, 354-374.

Otte, M., 1990. The northwestern European plain around 18,000 BP. In: The World at 18,000 BP, Vol. 1, Soffer, O., Gamble, C. (Eds.). Unwin Hyman, London, pp. 54-68.

Palma di Cesnola, A., 1990. Les pieces foliacées de l'Epigravettien ancien italien : leur origine, leur position chrono-stratigraphique. In: Feuilles de Pierre: Les Industries à Pointes Foliacées du Paléolithique Supérieur Européen, Kozlowski, J. (Ed.). E.R.A.U.L., Liège, Belgium, pp.503-512.

Palma di Cesnola, A., 2001. Le Paléolithique supérieur en Italie. Jerume Millon.

Pearson, R.G., Raxworthy, C.J., Nakamura, M., Peterson, A.T., 2007. Predicting species' distributions from small numbers of occurrence records: a test case using cryptic geckos in Madagascar. Journal of Biogeography 34, 102-117.

Peltier, W.R., 1994. Ice age paleotopography. Science 265, 195-201.

Peterson, A.T., 2003. Predicting the geography of species' invasions via ecological niche modeling. Quarterly Review of Biology 78, 419-433.

Peterson, A.T., Cohoon, K.C., 1999. Sensitivity of distributional prediction algorithms to geographic data completeness. Ecological Modelling 117, 159-164. 
Peterson, A.T., Ortega-Huerta, M.A., Bartley, J., Sánchez-Cordero, V., Soberón, J., Buddemeier, R.H., Stockwell, D.R.B., 2002. Future projections for Mexican faunas under global climate change scenarios. Nature, 416, 626-629.

Peterson, A.T., Bauer, J.T., Mills, J.N., 2004. Ecological and geographic distribution of filovirus disease. Emerging Infectious Diseases 10, 40-47.

Peyron, O., Guiot, J., Cheddadi, R., Tarasov, P., Reille, M., de Beaulieu, J.-L., Bottema, S., Andrieu, V., 1998. Climatic reconstruction in Europe for 18,000 yr B.P. from pollen data. Quaternary Research 49, 183-196.

PMIP, 2000. Paleoclimate Modeling Intercomparison Project (PMIP). Proceedings of the Third PMIP Workshop. WCRP-111, WMO/TD-No. 1007.

Raynaud, D., Jouzel, J., Barnola, J. M., Chapellaz, J., Delmas, R. J., Lorius C., 1993. The ice record of greenhouse gases. Science 259, 926-934.

Reimer, P.J., Baillie, M.G.L., Bard, E., Bayliss, A., Beck, J.W., Bertrand, C.J.H., Blackwell, P.G., Buck, C.E., Burr, G.S., Cutler, K.B., Damon, P.E., Edwards, R.L., Fairbanks, R.G., Friedrich, M., Guilderson, T.P., Hogg, A.G., Hughen, K.A., Kromer, B., McCormac, F.G., Manning, S.W., Ramsey, C.B., Reimer, R.W., Remmele, S., Southon, J.R., Stuiver, M., Talamo, S., Taylor, F.W., van der Plicht, J., Weyhenmeyer, C.E., 2004. IntCal04 terrestrial radiocarbon age calibration, 26-0 ka BP. Radiocarbon 46, 10291058.

Sánchez-Cordero, V., Martínez-Meyer, E., 2000. Museum specimen data predict crop damage by tropical rodents. Proceedings of the National Academy of Sciences USA 97, 7074-7077.

Sepulchre, P., Ramstein, G., Kageyama, M., Vanhaeren, M., Krinner, G., Sánchez-Goñi, M.-F., d'Errico, F., 2007. H4 abrupt event and late Neanderthal presence in Iberia. Earth and Planetary Science Letters, doi: 10.1016/j.epsl.2007.03.041.

Shackleton, N.J., Fairbanks, R.G., Chiu, T.-C., Parrenin, F., 2004. Absolute calibration of the Greenland time scale: Implications for Antarctic time scales and for $\Delta^{14} \mathrm{C}$. Quaternary Science Reviews 23, 1513-1522.

Smith, P.E.L., 1966. Le Solutréen en France. Mémoire No. 5, Publications de l'Institut de Préhistoire de l'Université de Bordeaux, France.

Soberón, J., Peterson, A.T., 2005. Interpretation of models of fundamental ecological niches and species' distributional areas. Biodiversity Informatics 2, 1-10.

Soberón, J., Peterson, A.T., 2004. Biodiversity informatics: Managing and applying primary biodiversity data. Philosophical Transactions of the Royal Society of London B 359, 689-698. 
Soffer O., Gamble, C. (Eds.), 1990. The World at 18,000 BP. Unwin Hyman, London.

Stockwell, D.R.B., 1999. Genetic Algorithms II. In: Machine Learning Methods for Ecological Applications, Fielding, A.H. (Ed.). Kluwer Academic Publishers, Boston, pp. 123-144.

Stockwell, D.R.B., Peters, D.P., 1999. The GARP modelling system: Problems and solutions to automated spatial prediction. International Journal of Geographic Information Systems 13, 143-158.

Stockwell, D.R.B., Peterson, A.T., 2002a. Effects of sample size on accuracy of species distribution models. Ecological Modelling 148:1-13.

Stockwell, D.R.B., Peterson, A.T., 2002b. Controlling bias in biodiversity data. In:

Predicting Species Occurrences: Issues of Scale and Accuracy, Scott, J.M., Heglund, P.J., Morrison, M.L. (Eds.). Island Press, Washington D.C., pp. 537-546.

Straus, L.G., 2005. The Upper Paleolithic of Cantabrian Spain. Evolutionary Anthropology 14, 145-158.

Straus, L.G., Bicho, N., Winegardner, A., 2000. Mapping the Upper Paleolithic regions of Iberia. Journal of Iberian Archaeology 2, 7-42.

Street, M., Terberger, T., 1999. The last Pleniglacial and the human settlement of Central Europe: New information from the Rhineland site of Wiesbaden-Igstadt. Antiquity 73, 259-272.

Stuiver, M., Reimer, P.J., Reimer, R.W., 2005. CALIB 5.0.2 [WWW program and documentation]. 14CHRONO Centre, Queen's University Belfast, URL:http://www.calib.org.

Texier, J.-P., 1996. Présence d'un réseau de grands polygones au sud de l'estuaire de la Gironde (France): Interprétation et implications paléoclimatiques. Géographie physique et Quaternaire 50, 103-108.

Torroni, A., Bandelt, H.J., Macaulay, V., Richards, M., Cruciani, F., Rengo, C., Martinez-Cabrera, V., Villems, R., Kivisild, T., Metspalu, E., Parik, J., Tolk, H.-V., Tambets, K., Forster, P., Karger, B., Francalacci, P., Rudan, P., Anicijevic, B., Rickards, O., Savontaus, M.-L., Huoponen, K., Laitinen, V., Koivumaki, S., Sykes, B., Hickey, E., Novelletto, A., Moral, P., Sellitto, D., Coppa, A., Al-Zaheri, N., Santachiara-Benerecetti, A.S., Semino, O., Scozzari, R., 2001. A signal, from human mtDNA, of postglacial recolonization in Europe. American Journal of Human Genetics 69, 844-852.

Torroni, A., Bandelt, H.-J., d'Urbano, L., Lahermo, P., Moral, P., Sellitto, D., Rengo, C., Forster, P., Savontaus, M.-L., Bonne'-Tamir, B., Scozzari, R., 1998. mtDNA analysis 
reveals a major late Paleolithic population expansion from southwestern to northeastern Europe. American Journal of Human Genetics 62, 1137-1152.

Van Andel, T.H., Davies, W. (Eds.), 2003. Neanderthals and modern humans in the European landscape during the last glaciation: Archaeological results of the Stage 3 Project. McDonald Institute for Archaeological Research, Cambridge.

Van der Plicht, J., 1999. Radiocarbon calibration for the Middle/Upper Paleolithic: a comment. Antiquity 73, 119-123.

van Vliet-Lanoë, B., 1996. Relations entre la contraction thermique des sols en Europe du nord ouest et la dynamique de l'inlandsis nord-européen au Weichsélien. C.R. de l’Académie des Sciences, Paris, Série II 322, 461-468.

van Vliet-Lanoë, B., 2005. La Planète des Glaces: Histoire et Environnements de Notre Ere Glaciare. Vuibert, Paris.

van Vliet-Lanoë, B., Meilliez, F., Maygari, A., 2004. Distinguishing between tectonic and periglacial deformations of quaternary continental deposits in Europe. Global and Planetary Change 43, 103-127.

Zilhão, J., d'Errico, F., 1999. The chronology and taphonomy of the earliest Aurignacian and its implications for the understanding of Neanderthal extinction. Journal of World Prehistory 13, 1-68. 


\section{List of Figures}

Figure 1: (A) Examples of Solutrean projectile points. Drawings are not to scale (adapted from Smith 1966); (B) Examples of Epigravettian projectile points recovered from Grotta di Paina. Scale bar is $1 \mathrm{~cm}$ (adapted from Palma di Cesnola, 2001).

Figure 2: High-resolution temperature and precipitation simulations for the Last Glacial Maximum (LGM) used in the GARP analyses: A) warmest month temperature $\left.\left({ }^{\circ} \mathrm{C}\right), \mathrm{B}\right)$ coldest month temperature $\left.\left({ }^{\circ} \mathrm{C}\right), \mathrm{C}\right)$ mean annual precipitation $\left.(\mathrm{mm} \times 100), \mathrm{D}\right)$ mean annual temperature $\left({ }^{\circ} \mathrm{C}\right)$. The values of warmest and coldest months refer to the warmest/coldest month in a climatic cycle averaged over 10 yrs of simulation.

Figure 3: Histograms of the percentages of uncalibrated conventional and AMS radiocarbon age determinations for the Solutrean technocomplex.

Figure 4: GARP prediction based on both Solutrean and Epigravettian sites dated to $21 \pm$ $1 \mathrm{kyr}$ cal BP. Grid squares with $1-5$ of 10 models predicting the presence of an ecocultural niche are indicated in grey, grid squares with 6-9 models in agreement are depicted in pink, and squares with all 10 models in agreement are indicated in red. Archaeological site locations (i.e. GARP occurrence points) are indicated by yellow circles.

Figure 5: Eco-cultural niche models for the Solutrean and Epigravettian technocomplexes at the Last Glacial Maximum. For each technocomplex, grid squares with 1-5 of 10 models predicting the presence of an eco-cultural niche are indicated in grey, grid squares with 6-9 models in agreement are depicted in pink, and squares with all 10 models in agreement are indicated in red. Archaeological site locations (i.e. GARP occurrence points on which the models were based) are indicated by yellow circles.

Figure 6: Plots of Solutrean and Epigravettian ecological niches based on simulated LGM coldest month temperature $\left({ }^{\circ} \mathrm{C}\right)$, warmest month temperature $\left({ }^{\circ} \mathrm{C}\right)$, mean annual temperature $\left({ }^{\circ} \mathrm{C}\right)$, and mean annual precipitation $(\mathrm{mm} \times 100)$.

Figure 7: Reconstructed limits of continuous and discontinuous permafrost conditions in France during the LGM (adapted from van Vliet-Lanoë et al., 2004:105): A) deep seasonally frozen, B) discontinuous permafrost, C) continuous permafrost, D) continuous deep permafrost.

\section{List of Tables}

Table 1: Epigravettian and Solutrean sites used to produce eco-cultural niche models. 
Table 1: Epigravettian and Solutrean sites used to produce GARP models.

\begin{tabular}{|c|c|c|c|c|c|c|c|c|c|}
\hline Site & culture & Long. & Lat. & Country & code & date & sd & Calib. & type \\
\hline Asprochaliko & Epigrav & 20.75 & 39.19 & Greece & OxA-775 & 18000 & 300 & 21365 & AMS \\
\hline Barma Grande & Epigrav & 7.53 & 44.34 & Italy & GifA-5072 & 17200 & 180 & 20333 & AMS \\
\hline Covolo Fortificato di Trene & Epigrav & 11.55 & 45.44 & & UtC-2691 & 17640 & 140 & 20822 & AMS \\
\hline Riparo del Broion & Epigrav & 11.6 & 45.48 & Italy & UtC-10506 & 17830 & 100 & 21059 & AMS \\
\hline Ponte di Pietra & Epigrav & 12.96 & 43.5 & Italy & CRG-1019 & 18515 & 618 & 21959 & AMS \\
\hline Fosso Mergaoni & Epigrav & 13.02 & 43.45 & Italy & UtC-11551 & 18160 & 240 & 21583 & AMS \\
\hline Grotta dei Fanciulli & Epigrav & 7.5 & 43.86 & Italy & diagnostics & LGM & & & $\mathrm{n} / \mathrm{a}$ \\
\hline Grotta della Cala & Epigrav & 15.37 & 40.18 & Italy & diagnostics & LGM & & & $\mathrm{n} / \mathrm{a}$ \\
\hline Rip. Maurizio & Epigrav & 13.65 & 42.01 & Italy & diagnostics & LGM & & & $\mathrm{n} / \mathrm{a}$ \\
\hline Grotta Tronci & Epigrav & 13.65 & 42.05 & Italy & diagnostics & LGM & & & $\mathrm{n} / \mathrm{a}$ \\
\hline Rip. Del Sambuco & Epigrav & 12.45 & 42.34 & Italy & diagnostics & LGM & & & $\mathrm{n} / \mathrm{a}$ \\
\hline Altamira & Solutrean & -4.12 & 43.38 & Spain & GifA-90045 & 18540 & 320 & 20048 & AMS \\
\hline Caldeirao & Solutrean & -8.42 & 39.65 & Portugal & OxA-2510 & 18840 & 200 & 20436 & AMS \\
\hline Combe Suaniere & Solutrean & 0.16 & 45.14 & France & OxA-488 & 17700 & 290 & 20940 & AMS \\
\hline Jean Blancs & Solutrean & 0.49 & 44.86 & France & GifA-97147 & 17650 & 200 & 20844 & AMS \\
\hline Grotte XVI & Solutrean & 1.2 & 44.8 & France & AA-2668 & 20070 & 330 & 22068 & AMS \\
\hline Buraca Escura & Solutrean & -8.73 & 39.98 & Portugal & Gif-4585 & 18040 & 230 & 21421 & Conv \\
\hline Placard & Solutrean & -0.03 & 45.8 & France & GifA-91184 & 19970 & 250 & 21948 & AMS \\
\hline Solutre & Solutrean & 4.31 & 46.38 & France & CAMS-36630 & 19720 & 70 & 21676 & AMS \\
\hline Vale Almoinha & Solutrean & -9.4 & 39.08 & Portugal & OxA-5676 & 19940 & 180 & 21932 & AMS \\
\hline
\end{tabular}


Figure 1

Click here to download high resolution image

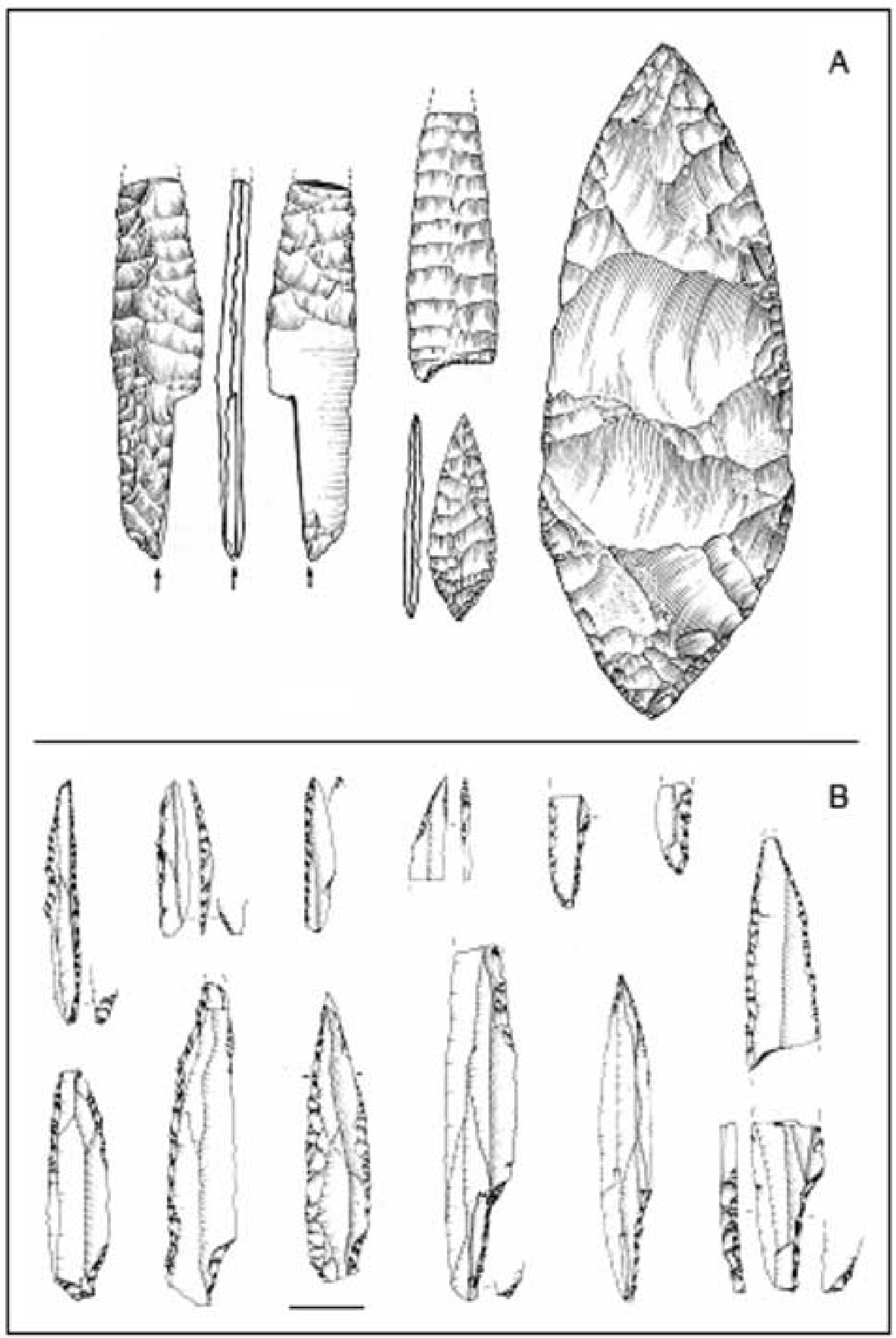


Click here to download high resolution image
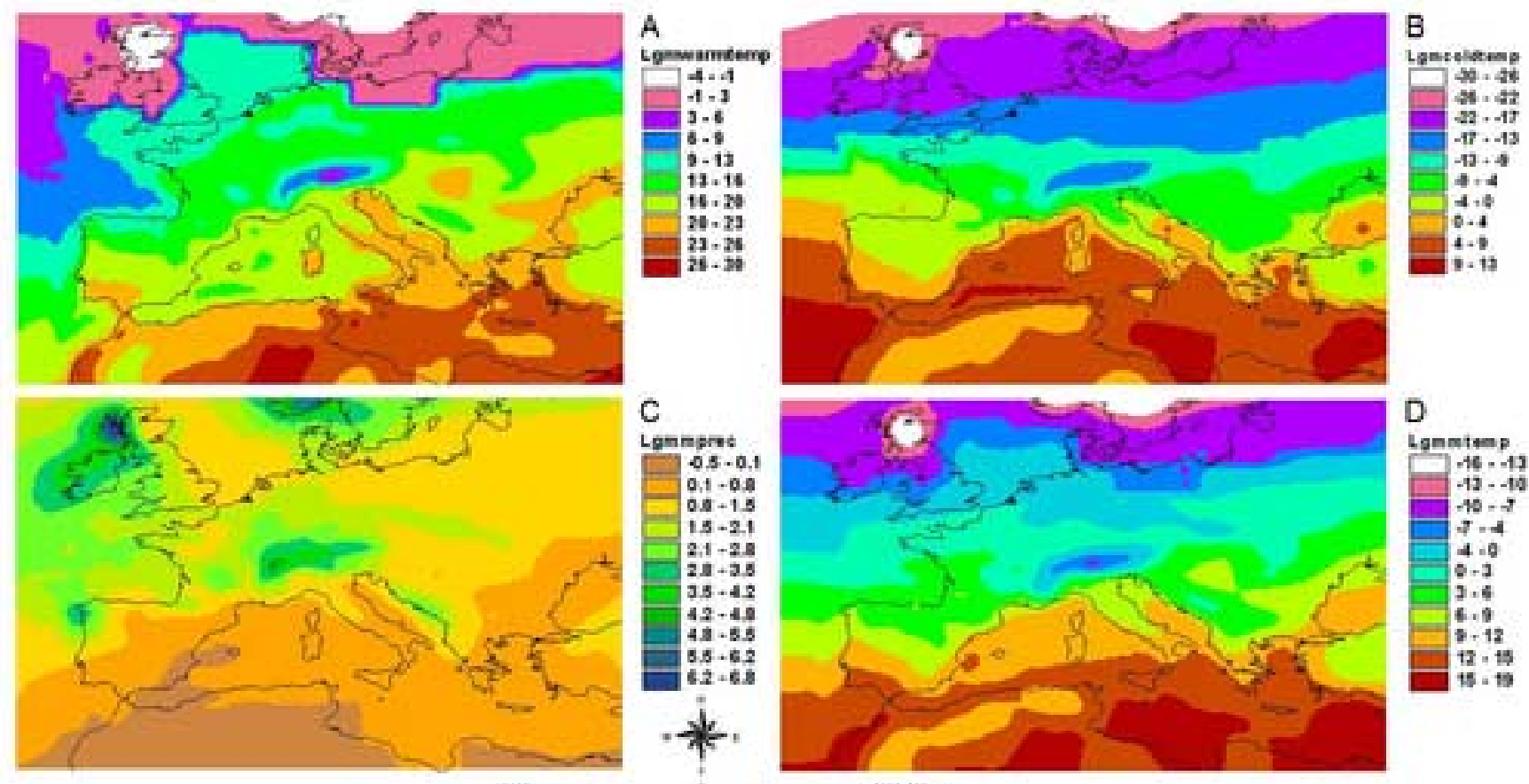

c

$0.5-0.1$
$0,1-0.9$

$0,0+1,5$

i. $1.5-2.1$

$2.1+2.8$
$2.8+3.5$

$2.9+3.5$
$3.5-4.5$ $4.2+40$ 4.9 .5 .5 $5.5-6.2$

$62+6.8$

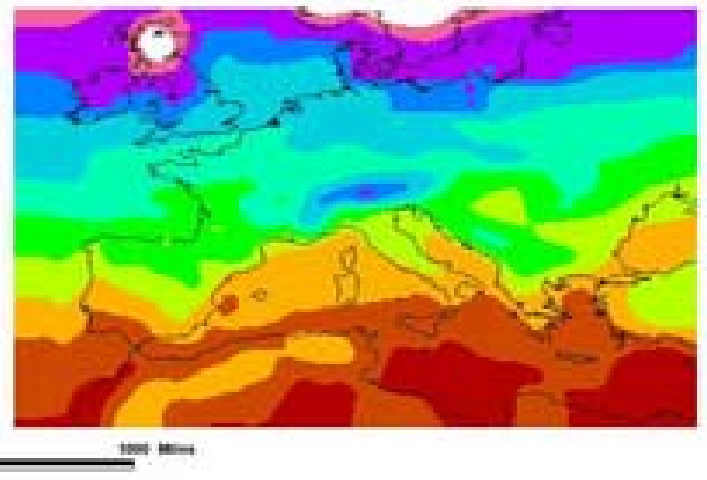

D

Lgnmtemp

${ }^{2}-16,-13$

$-12 \cdot-10$

190.7 $7=4$ $4: 9$

0.2

3.6 6.9 3. -12

15. 19

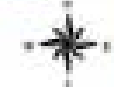


Figure 3

Click here to download high resolution image

$\%$
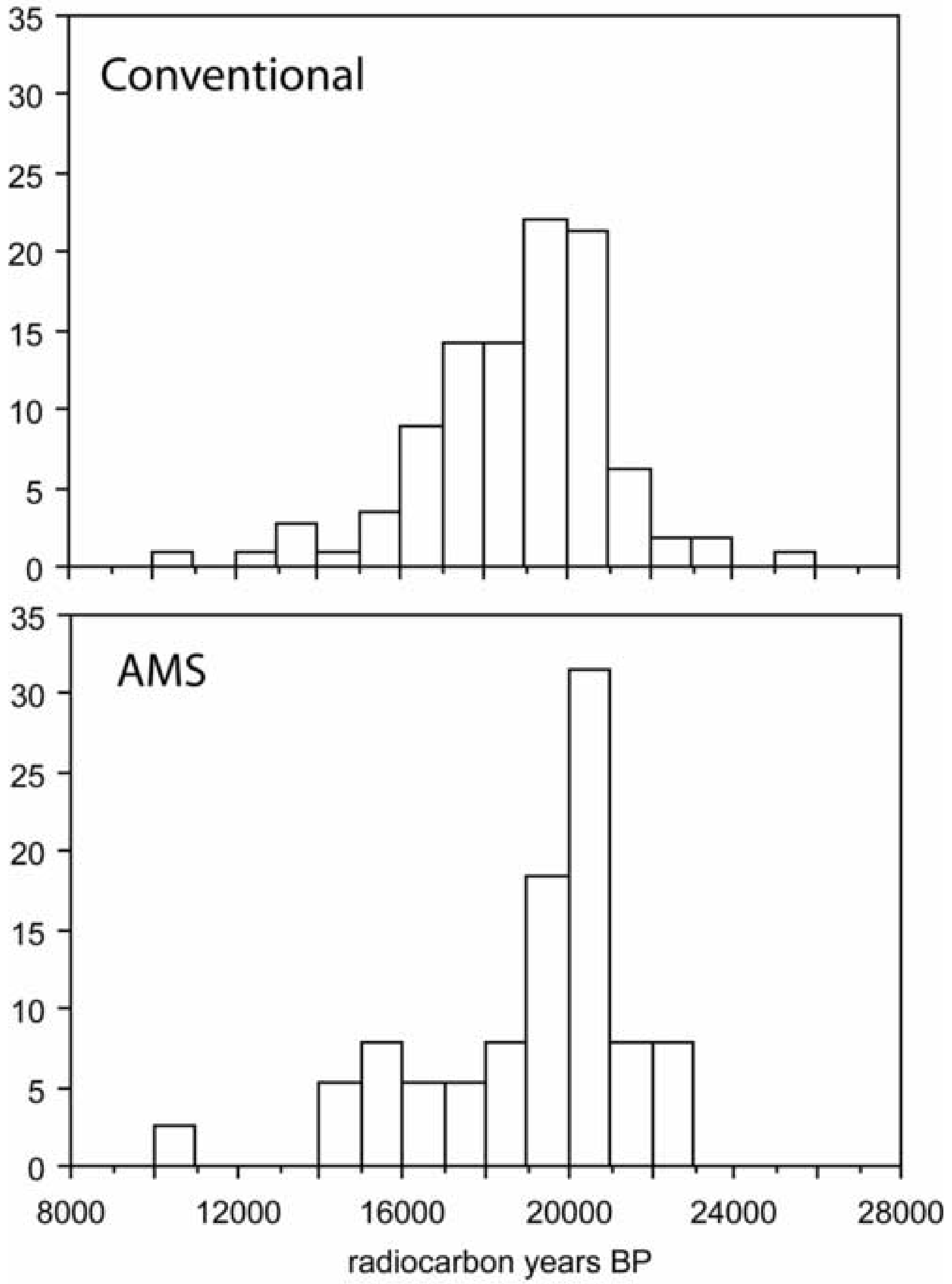
Figure 4

Click here to download high resolution image

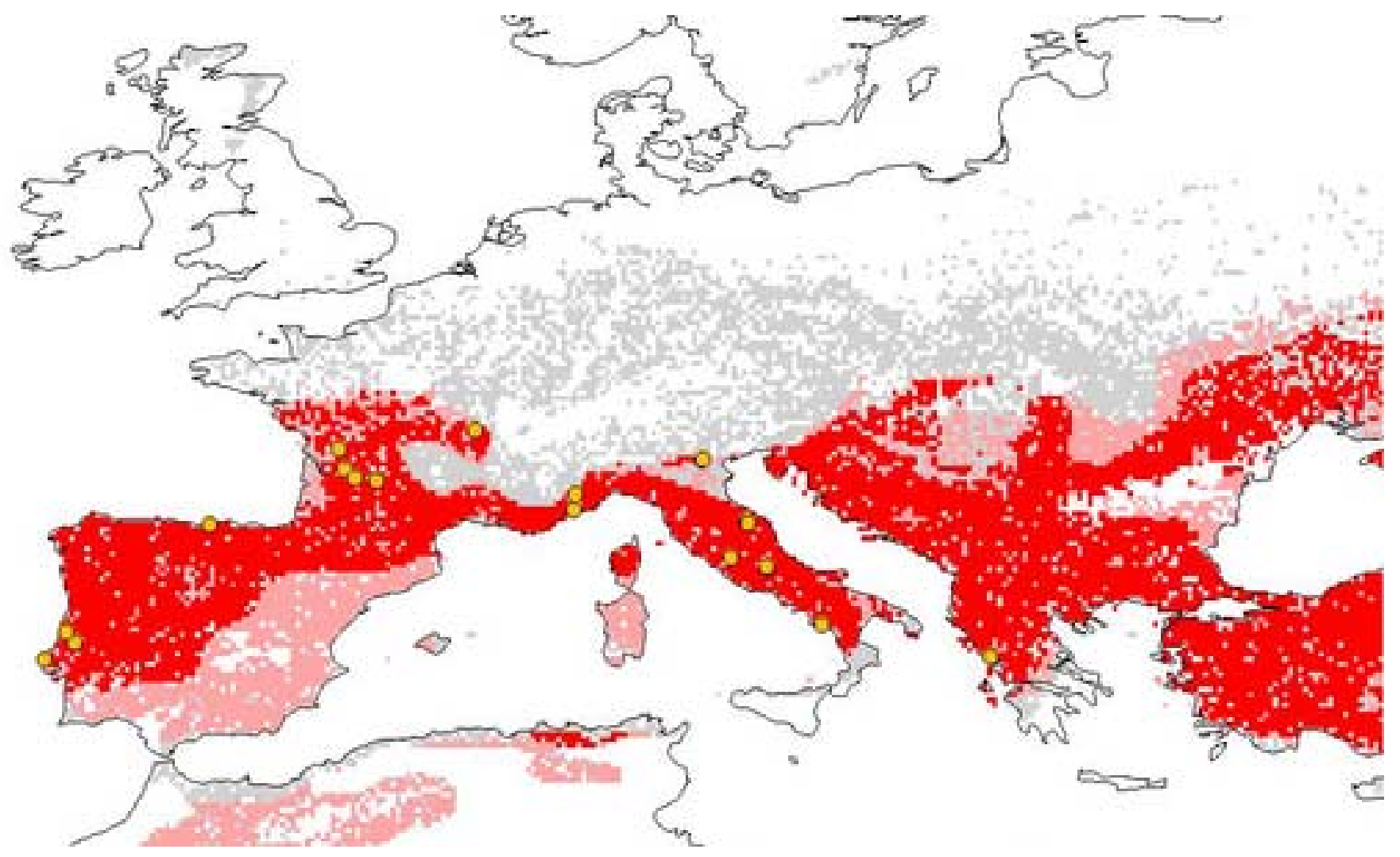


Figure 5

Click here to download high resolution image

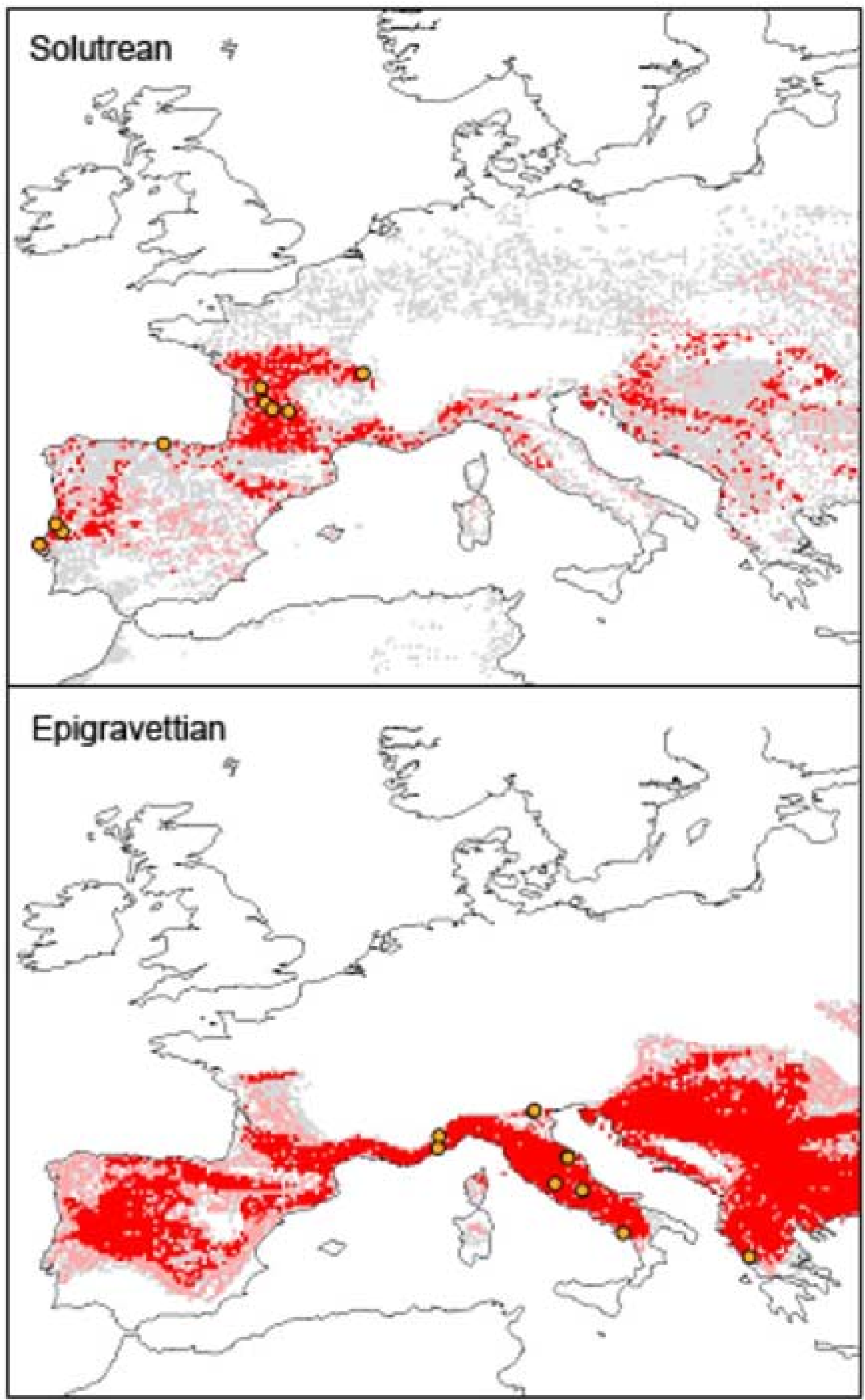


Figure 6

Click here to download high resolution image
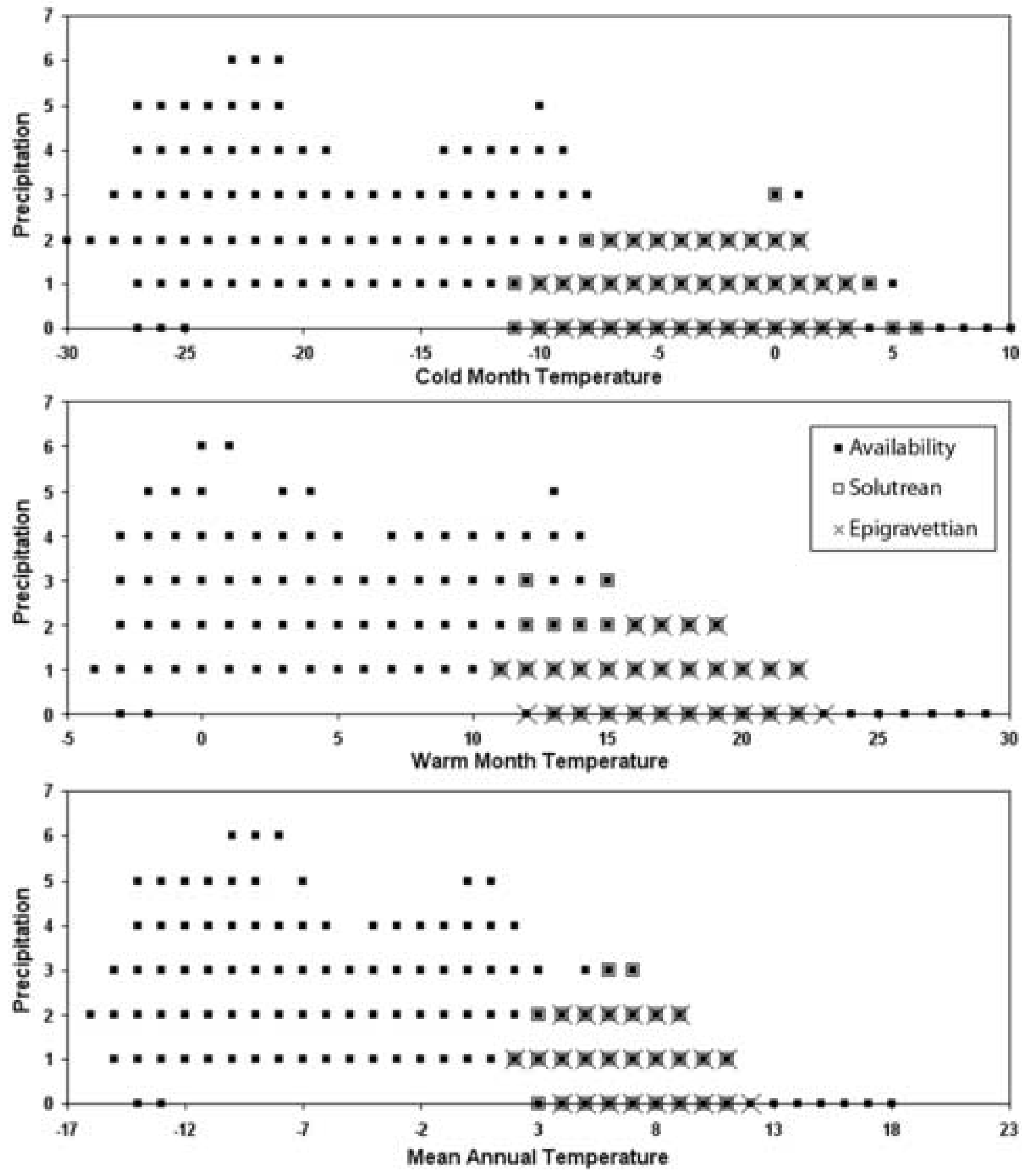
Figure 7
Click here to download high resolution image

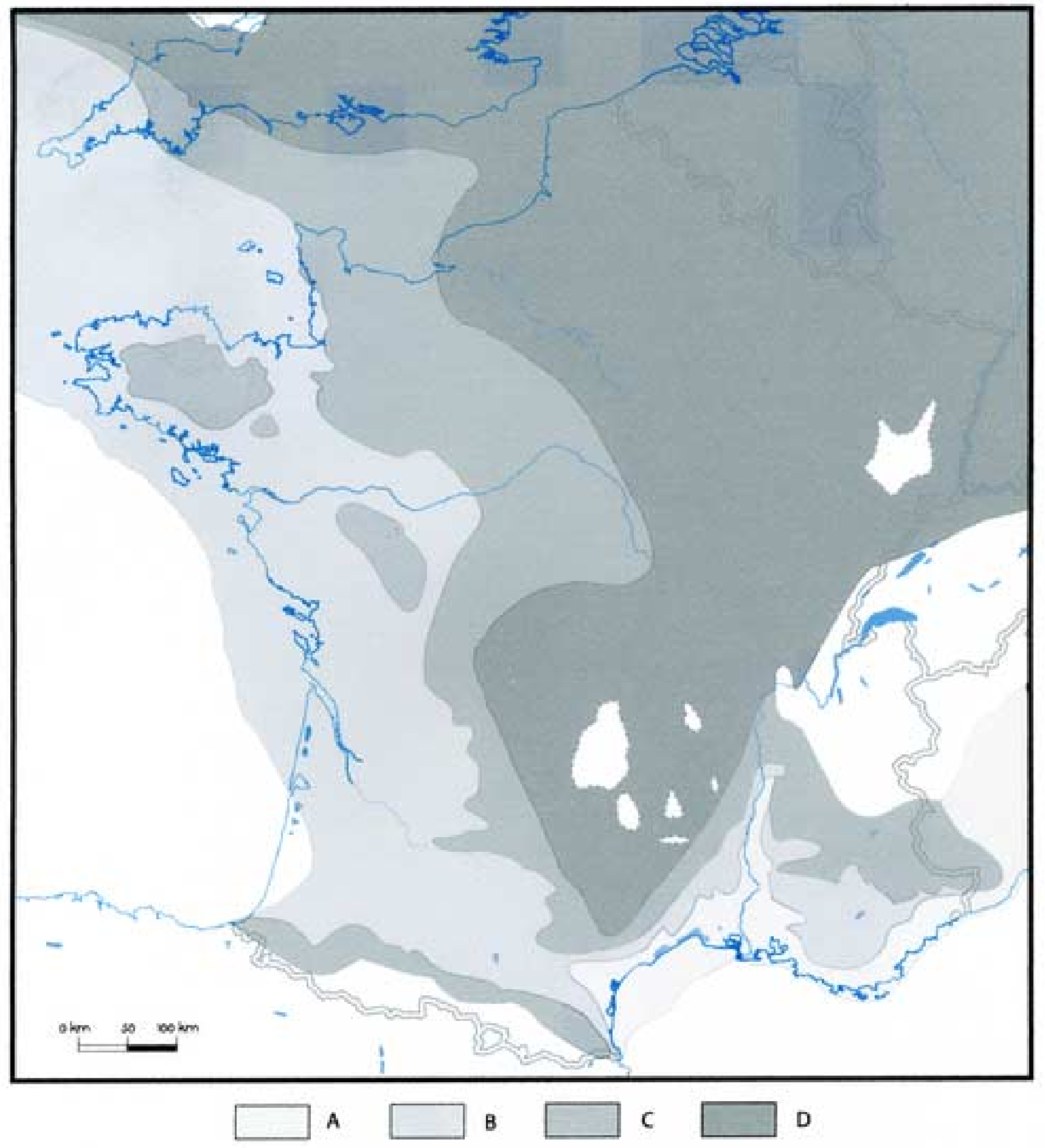

